\title{
STANDARDY PRO UŽÍVÁNÍ PSYCHOLOGICKÝCH TESTŮ - NASTAL ČAS PRO ČESKOU NORMU?
}

\author{
STANISLAV JEŽEK \\ Institut výzkumu dětí, mládeže a rodiny, Fakulta sociálních studií MU
}

\begin{abstract}
Užívání psychologických testů je spojeno s řadou problémů, což si ve světě vynutilo existenci řady standardů regulujících užívání testů. Domníváme se, že i v češtině by měl existovat takový dokument a předkládáme možnou strukturu takového dokumentu založenou na standardech ITC, EFPA a APA.
\end{abstract}

Psychologické testy (jako termín označující (i komplexní) standardizované postupy, jimiž ze vzorků chování lidí nebo skupin, usuzujeme či měříme jejich vybrané charakteristiky) jsou jednou z velmi významných složek (nástrojů) psychologické profese. Ačkoli, či možná právě proto, že užívání psychologických testů není nic jednoduchého, jejich podoba často svádí $\mathrm{k}$ ne zcela korektním způsobům užití. Přitom k užívání testů je vysoká motivace; vždyt' oprávnění je používat by se dalo přirovnat k pravomoci lékařủ předepisovat léky - pojí se zde funkčnost a statusový symbol. Problém nevhodného, neoprávněného, nebo nekompetentního užití testů je letitý a řeší jej psychologické organizace všech úrovní po celém světě.

Rádi bychom zde (znovu) otevřeli diskuzi nad tím, jakým způsobem u nás podporovat co nejlepší praxi užívání testů. Vycházíme při tom z recentních standardů Evropské federace psychologických asociací (EFPA, 2005), Americké psychologické asociace (APA, 2000) a International Test Commision (ITC, 2000). Cílem diskuze by mělo být vyjasnění (konkretizace) toho, co zahrnuje dobrou praxi užití psychologických testů v kontextu ČR a umožnit tak následnou informovanější diskuzi o způsobech zajištování a prosazování takové dobré praxe (vzdělání a certifikace uživatelů testů, osvěta testovaných, legislativní omezení dostupnosti...).

Užití psychologického testu vymezujeme v souladu s výše citovanými zahraničními standardy jako celý proces od identifikace konstruktu, který potřebujeme změřit, přes volbu testu, jeho administraci, vyhodnocení/skórování, analýzu a interpretaci skórů až po komunikaci výsledků. Ačkoli mohou zásadní problémy vzniknout i při tvorbě testu, pracovní skupina APA cituje britský výzkum Barbary Tyler (1986, cit. dle APA, 2000), podle něhož je většina problémů testovací praxe spojena spíše s jejich uživateli než s tvůrci/producenty testů. Proto se citované standardy zaměřují na užití testů a problémy (ne)kvality testů se zde řeší prostřednictvím deklarace potřeby kompetence uživatele identifikovat tuto (ne)kvalitu a zodpovědnost za užívání této kompetence. Jaké jsou tedy předpoklady dobrého užívání psychologických testů?

Dobrou praxi užívání testů lze rozdělit do tř́ vzájemně se prolínajících oblastí: (1) etika užití testů, (2) kvalita administrace a interpretace testu a (3) legální stránka užití testů. Do etické oblasti spadá především zodpovědnost za účelnost použití testu $k$ danému účelu a s určitým klientem, za kontrolu vlastní kompetence k užití testu, korektnost komunikace s testovaným a zajištění jeho práv na utajení osobních údajů, převzetí zodpovědnosti za užití testu. Do oblasti kvality administrace a interpretace testu spadá celé psychometrickostatisticko-administrační know-how. Uživatel musí být dostatečně obeznámen s pojmy konstrukce a fungování testu, aby uměl celý proces realizovat a rozuměl tomu, co dělá; aby neměl problém porozumět manuálu a pochopit a provést vše, co je manuálem předepsáno. 
Legální otázky užití testů zahrnují především nakládání testy v souladu s autorskými právy (nešiření, zabezpečení). V závislosti na oblasti užití sem obecně spadá i legislativa regulující psychologickou praxi. APA (2000) a ITC (2000) spojují etické a legální aspekty do jedné kategorie, EFPA(2005) rozděluje etickou oblast na obecnější eticko-profesní problémy (responsibility for ethical test use) a specifičtější problematiku odborné kompetence užívání testu, zodpovědnosti za volbu testu pro danou situaci, interpretaci a komunikaci výsledků (good practice in the use of tests). V následujícím podrobnějším popisu se podržíme členění EFPA.

\section{Etika užívání testu}

Podle EFPA (2005, s. 9, Unit 1) zahrnuje etické užití testů v nejobecnější rovině propagování a dodržování profesních a etických standardů, vytvoření a dodržování explicitní politiky testování a užívání testů, požadování téhož od spolupracovníků, komunikace s ohledem na citlivost zpracovávaných informací pro testovanou osobu a další zainteresované osoby, korektní prezentace testů a testování v médiích a vyhýbání se situacím osobní zainteresovanosti na výsledku užití testu (spor zájmů). Nejde tedy pouze o korektní opakované jednorázové užití testů, ale o požadavky vedoucí $\mathrm{k}$ tomu, aby celá praxe testování prosperovala. $\mathrm{V}$ osobní rovině se $\mathrm{k}$ tomu přidávají sebe-reflektivní požadavky na reflektování mezí vlastní kompetence a osobní zodpovědnost za udržování aktuálnosti svého vzdělání v oblasti testování obecně a konkrétních testů specificky. V rovině konkrétní situace užití testů sem spadá přijetí právní, etické i smluvní zodpovědnosti za volbu testu a jeho administraci (vč. př́padných spolupracujících osob), dostatečné informování testovaných osob (oboustranně jasný informovaný souhlas) a snaha vyhnout se nezamýšleným následků a jakékoli škodě účastníkům celého procesu. Určité části tohoto procesu tedy mohou dle uvážení uživatele testu realizovat další osoby, uživatel testu však přebírá zodpovědnost za jejich výkon. Při nakládání s testovými materiály se pokládá za etické dodržování autorských práv, a to pro ně samé, ale $\mathrm{v}$ př́ípadě předávání informací o testu třetím stranám i zajištěním, že nedojde k takovému zveřejnění materiálů či principů fungování testů, které by ohrozilo budoucí použití testu. Stejně pečlivě je třeba nakládat s osobními údaji testovaných osob; je třeba mít vypracovanou explicitní politiku zajišt'ující, že se osobní údaje nedostanou do neautorizovaných rukou, a to ani v budoucnosti. Jde především o zajištění bezpečnosti uložených dat a definování pravidel přístupu a nakládání s nimi.

Z kvalifikační perspektivy musí mít uživatel testu především přehled o výše uvedených nárocích na etičnost užívání testů.

\section{Odborná kompetence užití testu}

Do problematiky samotného užívání testů řadí standard EFPA (2005, Unit 2) schopnost kompetentně vyhodnotit potenciální prŕńos užití testu v diagnostické situaci. To zahrnuje identifikaci konstruktu, který je třeba změřit, zvážení výhod a nevýhod ne-testových způsobů získávání relevantních informací, zvážení rizik i schopnost to vše adekvátně komunikovat zúčastněným osobám. Dále sem spadá schopnost kompetentní volby testu na základě empiricky prokázaných silných a slabých stránek testů, k čemuž je třeba schopnost rozumět manuálům a empirickým a metaanalytickým výzkumným zprávám. $\mathrm{S}$ tím souvisí i průběžné sledování změn v charakteristikách běžně použivaných testů či u jejich cílových populací. Požaduje se schopnost zabývat se férovostí testů a identifikovat možná zkreslení vyplývající ze specifických charakteristik testované osoby (kultura, jazyk, hendikep...), kontextu testování, či jiných odchylek od standardního postupu. Samostatnou rozsáhlou oblastí je 
interpretace výsledků testu. Zde se očekává schopnost integrovat veškeré dostupné informace (nejen získané skóry), volit patřičné normy či referenční hodnoty, zvažovat alternativní interpretace, kombinovat věcné výsledky s technickými nedokonalostmi testu a uvážlivě využívat automaticky generované zprávy. Ani zde nechybí důraz na komunikaci výsledků různým zúčastněným osobám, včetně identifikace těchto zúčastněných osob, přizpůsobení odbornosti použitého jazyka jejich úrovni a zajištění jejich informovanosti o roli testu v kontextu celého diagnostického procesu. Do obrazu kompetentního uživatele testu patří také aktivní monitorování použitelnosti testu $\mathrm{v}$ tom smyslu, že uživatel sleduje změny v populaci, pro kterou je test určen, sleduje dopady užití testu (zvláště negativní), účastní se validizačních studií a poskytuje informace související s normami, reliabilitou a validitou nakladatelům/tvůrcům testu.

Odborná kompetence uživatele testu ve smyslu předchozího odstavce je tedy především psychodiagnostickou a psychometrickou kompetencí. Jde o znalosti a dovednosti na úrovni stanovení diagnostického postupu a nástrojů a zajištění realizace celého postupu včetně dobrého porozumění diagnostickým informacím, které zvolený postup skýtá.

\section{Kvalita administrace testu}

I když se úkol administrace testu může zdát snadný - vždyt' jde pouze o nacvičení a dodržení předepsaných postupů - psychologické vzdělání a zkušenosti umožňují uživateli testu dobře identifikovat a porozumět jednotlivým prvkům administrace a potenciálním následkům jejich nedodržení či modifikace. Do kvality administrace testu EFPA (2005, Unit 3) zahrnuje zajištění dostatečné přípravy na testovací sesi, korektní vlastní administraci testu a korektně provedené skórování testu. Osoba administrující test by měla být před administrací testu schopna zajistit patřičné informování všech zúčastněných o účelu testování, o jejich rolích v něm a způsobu nakládání s daty, popř. i o žádoucích způsobech př́ípravy na testování. To zahrnuje i poučení o právech a povinnostech a zajištění informovaného souhlasu. Měla by být schopná posoudit speciální potřeby konkrétního jedince, který má být testován (zejm. jazykové, percepční, pohybové apod.). Administrace samotná zahrnuje uvedení testované osoby do situace pozitivním způsobem snižujícím testovou úzkost včetně schopnosti poskytnout patřičnou podporu testovaným osobám, u nichž se stres a testová úzkost projeví v extrémní podobě. Jsou zde potřebné znalosti o dopadech testování a testové úzkosti na psychiku testovaných osob. Administrátor testu by měl být schopen zrealizovat všechny prvky postupu administrace specifikované manuálem s vědomím potenciálních následků odchýlení se od předepsaných postupů. Přritom je třeba být schopen vypořádat se s jakýmikoli odbornými či osobními otázkami testované osoby. Zároveň je třeba postřehnout a zaznamenat veškeré odchylky od standardního průběhu administrace. Nelze zapomenout na evidenci veškerých testových materiálů, aby na konci sese žádné nechyběly. I při striktním dodržení pokynů a instrukcí předepsaného manuálem metody je nutné být $\mathrm{v}$ prŕpadě potřeby $\mathrm{u}$ hendikepovaných osob schopen zvolit rozumné modifikace. Vyhodnocení výsledků testu ve své ideální podobě přesně sleduje manuálem předepsaný postup. Při vyhodnocování je třeba být schopen identifikovat nepravděpodobné či nesmyslné výsledky. Při tom je třeba se dobře vyznat $\mathrm{v}$ konvencích používaných při manipulacích (transformace, prepočty) s testovými skóry.

Úvaha o kvalifikaci pro kvalitní administraci testu nás vede především k požadavku psychometrických a metodologických znalostí zajišt'ujících to, že postupy a úkony požadované manuálem testu budou realizovány s porozuměním a vědomím konsekvencí odchylek od požadovaného postupu. Stejně tak důležitý je ale i zácvik a zkušenost 
s administrací daného testu nebo testu daného typu, osobnostní charakteristiky umožňující vysokou průběžnou úroveň administrace i sociální dovednosti v interakci s klienty.

\section{Účel a použití uvedených standardů}

Standardy, jejichž shrnutím jsou předchozí odstavce, jsou ve své obecnosti záměrně maximalistické. Popisují ideálního a do značné míry univerzálního uživatele testů. Nelze očekávat, že všichni lidé, kteří se na užívání testů podílejí, budou mít veškeré kompetence k zajištění všech uvedených požadavků na kvalitní užití všech testů. V různých oblastech užití testů mají navíc uvedené požadavky různou důležitost. Lze se tedy ptát, jaký je účel takových standardů.

Domníváme se, že účel maximalistických standardů je několikerý. Následujících šest oblastí rozhodně možnosti využití takového dokumentu nevyčerpává.

a) Shrnují v určité formě aktuální ,jádrové“ know-how o faktorech ovlivňujících kvalitu užití testu. „Jádrové“ zde používáme ve smyslu, empiricky ověřené, konsenzuálně akceptované faktory.

b) Mohou sloužit jako referenční materiál pro tvorbu kurikula psychologických vzdělávacích programů a dalších programů, jejichž absolventi pracují s testy (např. pedagogika, sociální práce).

c) Vzhledem k tomu, často celý proces užití testu uskutečňuje několik lidí. Lze tento materiál využít pro plánování skladby týmů, tak aby se členové týmu ve svých kompetencích účelně doplňovali a žádná důležitá kompetence nezůstala nezajištěna.

d) Mohou sloužit jako deklarace pro klienty, na kterou se mohou odkazovat uživatelé testů v situacích, kdy např. chtějí poukázat na to, v čem jsou lepší než konkurence, zda na určitém prvku postupu záleží, za co všechno klient platí, proč by měl chtít kvalifikovaného odborníka apod.

e) Mohou sloužit jako deklarace pro zainteresovanou veřejnost a média informující o tom, co považuje odborná komunita za žádoucí. Na standard se lze odkazovat i ve sporech o to, zda je nějaký diagnostický postup (např. placený z peněz daňových poplatníků) v pořádku.

f) Obecný standard je vhodným východiskem pro tvorbu specifičtějších norem pro specifické oblasti praxe užití testů. Specifika užití testu v organizačním, vzdělávacím, kariérovém, zdravotnickém a forenzním kontextu zahrnuje např. standard APA (2000). Standard EFPA (2000) je šíře zaměřen na pracovní a organizační kontext.

Předkládáme zde výtah ze standardů ITC, EFPA a APA jako materiál pro diskuzi o možném vzniku českých standardů, které by mohly sloužit výše uvedeným účelům. Pokud by se nenalezly věcné důvody, proč tak neučinit, navrhovali bychom přihlásit se ke standardu EFPA nebo ITC a zpracovat oficiální český překlad. Ten by pak mohl být doplněn o česká specifika. 


\section{Literatura}

American Psychological Association (2000). Report of the task force on test user qualifications. Dostupné Z www: http://www.apa.org/science/programs/testing/qualifications.pdf

European Federation of Psychologists' Associations (2005). European test user standards for test use in work and organizational settings. Version 1.92. Dostupné $\mathrm{z}$ www: http://www.efpa.eu/download

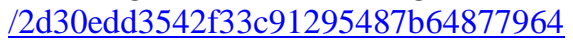

International Test Commission (2000). Intenational guidelines for test use. Version 2000. Dostupné z www: http://www.intestcom.com/itc_projects.htm

Mgr. Stanislav Ježek, Ph.D.

IVDMR FSS MU

Joštova 10

60200 Brno

e-mail: stan@fss.muni.cz 